\title{
Possession as the Origin of Property
}

\author{
Carol M. Rose†
}

How do things come to be owned? This is a fundamental puzzle for anyone who thinks about property. One buys things from other owners, to be sure, but how did the other owners get those things? Any chain of ownership or title must have a first link. Someone had to do something to anchor that link. The law tells us what steps we must follow to obtain ownership of things, but we need a theory that tells us why these steps should do the job.

John Locke's view, once described as "the standard bourgeois theory," is probably the one most familiar to American students. Locke argued that an original owner is one who mixes his or her labor with a thing and, by commingling that labor with the thing, establishes ownership of it. ${ }^{2}$ This labor theory is appealing because it appears to rest on "desert," but it has some problems. First, without a prior theory of ownership, it is not self-evident that one owns even the labor that is mixed with something else. ${ }^{*}$ Second, even if one does own the labor that one performs, the labor theory provides no guidance in determining the scope of the right that

† Professor of Law, Northwestern University, and Visiting Professor of Law, University of Chicago. For comments and suggestions I especially thank the George Washington University Property Colloquium, to which a version of this paper was given in March 1983, and Mary Ann Glendon, Victor Goldberg, Thomas Grey, Thomas Merrill, Frank Michelman, Phyllis Palmer, Daniel Polsby, and Rayman Solomon. All errors are of course my own.

1 Richard Schlatter, Private Property: The History of an Idea 151 (1951).

2 John Locke, Second Treatise of Government $\$ 25$, in Two Treatises of Government 327 (P. Laslett rev. ed. 1960) (1st ed. London 1690).

3 Lawrence Becker, Property Rights: Philosophic Foundations 49 (1977) (psychological sense of desert a driving force behind the appeal of labor theory).

- Locke's assertion that one owns one's labor is quite cryptic and appears to rest on the equally cryptic assertion that one owns one's body and thus the products of the body's exertions. See J. LockE, supra note 2, § 27, at 329, § 28, at 330. Richard Epstein argues that for Locke, the reason one owns one's body is that one occupies or possesses it; thus, this labor theory of property rests on a right established by first possession. See Epstein, Possession as the Root of Title, 13 GA. L. REv. 1221, 1227-28 (1979). But Locke himself did not argue that ownership of the body and its labors rests on possession. Indeed, the view that one owns one's body would be equally compatible with the theory that ownership of one's body or labor rests on the consent of mankind. Locke himself did reject the idea that property was based on the express consent of humanity. See J. LockE, supra note $2, \S 25$, at 327 , $\S 29$, at 331 . For a discussion of the consent theory, see infra notes 6-7 and accompanying text. 
one establishes by mixing one's labor with something else. Robert Nozick illustrates this problem with a clever hypothetical. Suppose I pour a can of tomato juice into the ocean: do I now own the seas?"

A number of thinkers more or less contemporary to Locke proposed another theory of the basis of ownership. According to this theory, the original owner got title through the consent of the rest of humanity (who were, taken together, the first recipients from God, the genuine original owner). ${ }^{6}$ Locke himself identified the problems with this theory; they involve what modern law-and-economics writers would call "administrative costs." How does everyone get together to consent to the division of things among individuals??

The common law has a third approach, which shares some characteristics with the labor and consent theories but is distinct enough to warrant a different label. For the common law, possession or "occupancy" is the origin of property. ${ }^{8}$ This notion runs through a number of fascinating old cases with which teachers of

- Robert Nozick, Anarchy, State and Utopia 175 (1974). The example rests on the argument that Locke's labor theory of property means that one acquires property by mixing what one owns (one's labor) with what one does not own. Nozick substitutes the can of tomato juice for one's labor.

- See, e.g., Hugo Grotius, ON the Law of War and Peace bk. 2, ch. 2, 11 1, 4-5 (Kelsey trans. 1925) (1st ed. Amsterdam 1646); J. LockE, supra note 2, at 327-28, editor's note to lines 18-21; see also id. at 114, editor's introduction. For Blackstone's brief discussion of the conflicts among natural law theorists over labor and consent theories, see 2 WILLIAM BLACKStone, Commentaries on the Laws of England *8 ("A dispute that savours too much of nice and scholastic refinement!').

' See J. Locke, supra note $2, \S 28$, at 330 ("If such a consent as that [of all humanity for individual gathering of wild acorns or apples] was necessary, Man had starved, notwithstanding the Plenty God had given him."); see also id. § 29, at 331 (requiring explicit consent would result in prohibitive costs of allocating "to everyone his particular part"). Robert Filmer, against whose work Locke directed his Treatises, had also noted this problem. See the edition of Filmer's Patriarcha in John Locke, Two Treatises on Civil Government 249-308 (T. Cook ed. 1947). A possible answer is that consent takes the passive or negative form of acquiescence: humanity might be viewed as consenting to those individual claims to which no one objects. See Samuel von Pufendorf, Le Drort de la Nature et des Gens liv. 4, ch. 4, $\S 9$ (J. Barbeyrac trans. 5th ed. 1734) (1st ed. Lund 1672). It is possible to read Locke's property theory in this light, and indeed such a reading might resolve the contradiction between his stated views that (1) God gave the world to all mankind in common, but (2) all mankind need not consent to individual appropriation. J. LockE, supra note $2, \S 25$, at 327; cf. W. BlackSTONE, supra note 6, at *8 (interpreting Locke as disputing the implied as well as the express consent theory).

${ }^{8}$ W. Blackstone, supra note 6 , at *8. Richard Epstein notes some ways in which the doctrine of first possession differs from a labor theory. See Epstein, supra note 4, at 122526. He also distinguishes the possession doctrine from a theory of property based on custom and common practice. Id. at 1234-35. My view is that a custom theory is a version of the theory of universal consent. 
property law love to challenge their students. Such inquiries into the acquisition of title to wild animals and abandoned treasure may seem purely academic; how often, after all, do we expect to get into disputes about the ownership of wild pigs or long-buried pieces of eight? These cases are not entirely silly, though. People still do find treasure-laden vessels, ${ }^{9}$ and statesmen do have to consider whether someone's acts might support a claim to own the moon, for example, or the mineral nodes at the bottom of the sea. ${ }^{10}$ Moreover, analogies to the capture of wild animals show up time and again when courts have to deal on a nonstatutory basis with some "fugitive" resource that is being reduced to property for the first time, such as oil, ${ }^{11}$ gas, ${ }^{12}$ groundwater, ${ }^{13}$ or space on the spectrum of radio frequencies. ${ }^{14}$

With these more serious claims in mind, then, I turn to the maxim of the common law: first possession is the root of title. Merely to state the proposition is to raise two critical questions: what counts as possession, and why is it the basis for a claim to title? ${ }^{15}$ In exploring the quaint old cases' answers to these ques-

- See, e.g., Treasure Salvors, Inc. v. Unidentified Wrecked \& Abandoned Sailing Vessel, 569 F.2d 330 (5th Cir. 1978).

10 For the history and theory of the "global common," including the high seas, the polar regions, and outer space, see AleXandra M. Post, DeEpsea Mining and the Law of the Sea ch. 6 (1983).

11 See, e.g., Jones v. Forest Oil Co., 194 Pa. 379, 44 A. 1074 (1899).

12 See, e.g., Westmoreland \& Cambria Natural Gas Co. v. DeWitt, 130 Pa. 235, 239, 18 A. 724, 725 (1889).

13 Louisiana courts have viewed percolating groundwater as unowned until "captured." See Adams v. Grigsby, 152 So. 2d 619, 624 (La. App.), cert. refused 244 La. 662, 153 So. 2d 880 (1963). Some other states have followed the "English Rule" of Acton v. Blundell, 12 Mees \& W. 324, 152 Eng. Rep. 1223 (Ex. 1843) (treating groundwater as a part of the property of the landowner, who can take as much as he likes so long as the use is neither wanton nor malicious). See City of Corpus Christi v. City of Pleasanton, 154 Tex. 289, 292-93, 276 S.W.2d 798, 801 (1955); Houston \& T.C. Ry. v. East, 98 Tex. 146, 151, 81 S.W. 279, 281-82 (1904). This rule may in fact not differ greatly from a rule of capture or first possession, since an owner cannot complain of loss of his water if it "escapes" to and is "captured" by a neighbor. Other states treat property in percolating groundwater under an "American" doctrine that limits the rights to "capture" subsurface water to such "reasonable use" as is compatible with the reasonable use of other owners. See Bassett v. Salisbury Mfg. Co., 43 N.H. 569, 577-78 (1862); Forbell v. City of New York, 164 N.Y. 522, 526, 58 N.E. 644, 645-46 (1900).

14 Cf. Rowley, Problems in the Law of Radio Communication, 1 U. Cin. L. Rev. 1, 27-31 (1927) (disputing the applicability to radio frequencies of the analogy to capture of wild animals).

${ }^{15}$ Professor Epstein discusses the doctrine of possession from a perspective rather different from that presented here; he views the question of what counts as "possession" as the "little question," and concentrates instead on the "big question," viz., why possession counts as a basis of title at all. Epstein, supra note 4, at 1225. Without going into the big/little issue, my view is that one cannot meaningfully ask why possession is a root of title unless 
tions, we hit on some fundamental views about the nature and purposes of a property regime.

Consider Pierson v. Post, ${ }^{16}$ a classic wild-animal case from the early nineteenth century. Post was hunting a fox one day on an abandoned beach and almost had the beast in his gunsight when an interloper appeared, killed the fox, and ran off with the carcass. The indignant Post sued the interloper for the value of the fox on the theory that his pursuit of the fox had established his property right to it.

The court disagreed. It cited a long list of learned authorities to the effect that "occupancy" or "possession" went to the one who killed the animal, or who at least wounded it mortally or caught it in a net. These acts brought the animal within the "certain control" that gives rise to possession and hence a claim to ownership. ${ }^{17}$

Possession thus means a clear act, whereby all the world understands that the pursuer has "an unequivocal intention of appropriating the animal to his individual use."18 A clear rule of this sort should be applied, said the court, because it prevents confusion and quarreling among hunters (and coincidentally makes the judges' task easier when hunters do get into quarrels).

The dissenting judge commented that the best way to handle this matter would be to leave it to a panel of sportsmen, ${ }^{19}$ who presumably would have ruled against the interloper. In any event, he noted that the majority's rule would discourage the useful activity of fox hunting: who would bother to go to all the trouble of keeping dogs and chasing foxes if the reward were up for grabs to any "saucy intruder"? ${ }^{20}$ If we really want to see that foxes don't overrun the countryside, we will allocate a property right-and thus the ultimate reward-to the hunter at an earlier moment, so that he will undertake the useful investment in keeping hounds and the useful labor in flushing the fox.

The problem with assigning "possession" prior to the kill is, of course, that we need a principle to tell us when to assign it. Shall we assign it when the hunt begins? When the hunter assembles his

one has some idea of what is meant by "possession." Epstein does, I believe, have an unstated idea of what is meant by possession; the purpose of the present article is to make such ideas more explicit.

${ }^{18} 3$ Cai. R. 175 (N.Y. Sup. Ct. 1805).

${ }^{17}$ Id. at 178.

18 Id.

19 Id. at 180 (Livingston, J., dissenting).

${ }^{20}$ Id. at 181. 
dogs for the hunt? When the hunter buys his dogs?21

Pierson thus presents two great principles, seemingly at odds, for defining possession: (1) notice to the world through a clear act, and (2) reward to useful labor. The latter principle, of course, suggests a labor theory of property. The owner gets the prize when he "mixes in his labor" by hunting. On the other hand, the former principle suggests at least a weak form of the consent theory: the community requires clear acts so that it has the opportunity to dispute claims, but may be thought to acquiesce in individual ownership where the claim is clear and no objection is made. ${ }^{22}$

On closer examination, however, the two positions do not seem so far apart. In Pierson, each side acknowledged the importance of the other's principle. Although the majority decided in favor of a clear rule, it tacitly conceded the value of rewarding useful labor. Its rule for possession would in fact reward the original hunter most of the time, unless we suppose that the woods are thick with "saucy intruders." On the other side, the dissenting judge also wanted some definiteness in the rule of possession. He was simply insisting that the acts that sufficed to give notice should be prescribed by the relevant community, namely hunters or "sportsmen." Perhaps, then, there is some way to reconcile the clear-act and reward-to-labor principles.

The clear-act principle suggests that the common law defines acts of possession as some kind of statement. As Blackstone said, the acts must be a declaration of one's intent to appropriate..$^{23}$ This possibility is illustrated in a later nineteenth-century case involving possession of land. Brumagim v. Bradshaw ${ }^{24}$ involved two claimants to a considerable amount of land that had become, by the time the litigation was brought, the residential and commercial Potrero district of San Francisco. Each party claimed ownership of the land through a title extending back to an original "possessor" of the land, and the issue was whether the first of these purported possessors, one George Treat, had really "possessed" the land at

${ }^{21}$ For a similar problem concerning ownership of oil and gas, having to do with uncertainties about the point at which to attribute "possession" to one who claims a fugitive resource, compare Hammonds v. Central Ky. Natural Gas Co., $255 \mathrm{Ky} .685,689,75$ S.W.2d 204, 206 (1934) (gas withdrawn from earth and then pumped back for storage is comparable to animal returned to wild and may thus be tapped by a neighbor), with Westmoreland \& Cambria Natural Gas Co. v. DeWitt, 130 Pa. 235, 250, 18 A. 724, 725 (1889) (oil and gas in the ground are "possessed" if all equipment is in place to tap at any time).

${ }_{22}$ See supra note 6 and accompanying text.

2s W. Blackstone, supra note 6 , at *9, *258.

2439 Cal. 24 (1870). 
all. If he had not, his successors in interest could not claim ownership through him, and title would go to those claiming through a later "first possessor."

Those who claimed through Treat put a number of facts before the jury to establish his original possession. They noted particularly that Treat had repaired a fence across the neck of the Potrero peninsula-to which the other side rejoined that outsiders could still land in boats, and that, in any event, there was a gap in the fence. ${ }^{26}$ The Treat claimants also alleged that Treat had made use of the land by pasturing livestock on it-though the other side argued that the land had not been suitable for cattle even then, because San Francisco was expanding in that direction. ${ }^{26}$ The court ruled that the jury should decide whether Treat's acts gave sufficient notice to the public that he had appropriated the property. ${ }^{27}$ If so, he had "possessed" it and could pass it on as an owner.

This instruction would seem to come down clearly on the side of the "clear act" theory of possession. Yet that theory seems to leave out some elements of the evidence. The fence question, to be sure, bore on whether Treat's acts informed the public of his claim. But the parties' arguments over whether Treat's use was "suitable" seemed to reflect concern over an aim of rewarding useful labor. If suitable use were a relevant issue, why did the court's jury instruction ignore the value of rewarding labor?

The answer to this question may well be that suitable use is also a form of notice. If outsiders would think that a large area near a growing city was abandoned because it was vacant except for a few cows, they might enter on the land and claim some prime waterfront footage for themselves. In other words, if the use that Treat made was unsuitable, his use would not give notice of his claim to others. Thus, to ask whether Treat used the land suitably is just another way of asking whether he informed others of his claim, particularly those others who might have been interested in buying the land from Treat or settling it for themselves. Society is worst off in a world of vague claims; if no one knows whether he can safely use the land, or from whom he should buy it if it is already claimed, the land may end up being used by too many people or by none at all.

Possession now begins to look even more like something that requires a kind of communication, and the original claim to the

\footnotetext{
25 Id. at 30 .

${ }^{26}$ Id. at $41-42$.

${ }^{27}$ Id. at 51 .
} 
property looks like a kind of speech, with the audience composed of all others who might be interested in claiming the object in question. Moreover, some venerable statutory law obligates the acquiring party to keep on speaking, lest he lose his title by "adverse possession."

Adverse possession is a common law interpretation of statutes of limitation for actions to recover real property. ${ }^{28}$ Suppose I own a lot in the mountains, and some stranger to me, without my permission, builds a house on it, clears the woods, and farms the lot continuously for a given period, say twenty years. During that time, I am entitled to go to court to force him off the lot. But if I have not done so at the end of twenty years, or some other period fixed by statute, not only can I not sue him for recovery of what was my land, but the law recognizes him as the title owner. ${ }^{29}$ The doctrine of adverse possession thus operates to transfer property to one who is initially a trespasser if the trespasser's presence is open to everyone, lasts continuously for a given period of time, and if the title owner takes no action to get rid of him during that time.

Here again we seem to have an example of a reward to the useful laborer at the expense of the sluggard. But the doctrine is susceptible to another interpretation as well; it might be designed, not to reward the useful laborer, but to require the owner to assert her right publicly. It requires her to make it clear that she, and not the trespasser, is the person to deal with if anyone should wish to buy the property or use some portion of it.

Courts have devoted much attention to the elements of a successful claim of adverse possession. Is grazing livestock a continuous use, so as to entitle the livestock owner to claim full ownership of the pasture as an adverse possessor? ${ }^{30}$ How about farming (where intensive use may be merely seasonal) or taking care of a lawn $?^{31}$ Is a cave that encroaches deep under my land something that is obvious to me, so that I should be required to kick out the trespasser who operates it as a commercial attraction $?^{32}$ No matter

287 Richard Powell, The Law of Real Property I 1012 (P. Rohan rev. ed. 1984).

${ }^{20}$ Id. I 1025; Ballantine, Title by Adverse Possession, 32 Harv. L. Rev. 135, 141 (1918).

so See, e.g., Halsey v. Humble Oil \& Refining Co., 66 S.W.2d 1082, 1087 (Tex. Civ. App. 1933) (yes, even though the cattle had to be removed when a nearby river flooded); $c$. McShan v. Pitts, 554 S.W.2d 759, 763-64 (Tex. Civ. App. 1977) (no, at least when the grazing was merely "casual" and was not so intense as to reach the limits of the pasture's capacity).

31 See Ramapo Mfg. Co. v. Mapes, 216 N.Y. 362, 372-73, 110 N.E. 772, 776 (1915) (cutting grass may establish "cultivation" that establishes adverse possession claim under New York statute).

32 See Marengo Cave Co. v. Ross, 212 Ind. 624, 10 N.E.2d 917 (1937) (occupying claimant does not acquire title to that portion of cave underlying surface titleholder's property 
how much the doctrine of adverse possession seems to reward the one who performs useful labor on land at the expense of the lazy owner who does nothing, the crucial element in all these situations is, once again, communication. "Possession" means acts that "apprise the community[,] . . . arrest attention, and put others claiming title upon inquiry." "33

In Illinois, for example, an adverse possessor may establish his claim merely by paying taxes on the property, at least against an owner who is familiar with real estate practice and records. ${ }^{34}$ Why is this? Naturally the community likes to have taxes paid and is favorably disposed toward one who pays them. But more important, payment of taxes is a matter of public record, and the owner whose taxes are paid by someone else should be aware that something peculiar is happening. ${ }^{35}$ Just as important, the public is very likely to view the taxpayer as the owner. If someone is paying taxes on my vacant lot or empty house, any third person who wants to buy the house is very likely to think that the taxpayer is the owner because people do not ordinarily pay taxes on land they do not own. If I want to keep my land, the burden is upon me to correct the misimpression. The possibility of transferring titles through adverse possession once again serves to ensure that members of the public can rely upon their own reasonable perceptions, and an owner who fails to correct misleading appearances may find his title lost to one who speaks loudly and clearly, though erroneously.

because occupancy was not open and notorious).

${ }^{33}$ Slatin's Properties, Inc. v. Hassler, 53 Ill. 2d 325, 329, 291 N.E.2d 641, 643 (1972) (quoting Chicago Title \& Trust Co. v. Drobnick, 20 Il. 2d 374, 379, 169 N.E.2d 792, 796 (1960)).

34 Slatin's Properties, Inc. v. Hassler, 53 IIl. 2d 325, 331, 291 N.E.2d 641, 644 (1972); see also Limitations Act § 7, ILL. REV. STAT. ch. 110, § 13-110 (1983) (legal title to vacant land established by paying taxes in good faith for seven years). In some western states, no adverse possession claims are allowed unless taxes are paid and recorded. See Comment, Payment of Taxes as a Condition of Title by Adverse Possession: A Nineteenth Century Anachronism, 9 Santa Clara L. Rev. 244, 244 (1969). This was designed to protect the railroads, who could not police their vast holdings and needed notice through the assessors' offices. Id. at 248-49. Such a rule again suggests the communicative aspect of adverse possession: claims ought not run against those who are incapable of "hearing" the message given by the would-be adverse possessor. The same may be said of the classes of owners, mentioned infra note 35 , whose properties are normally treated as immune from adverse possession claims.

${ }^{33}$ An owner who is unlikely to notice such an oddity may be exempt from adverse possession claims. These claims normally do not run against mental incompetents or children or certain other "disabled" owners who might be thought unable to perceive or act on events that would constitute notice to ordinary adults. See, e.g., N.J. REv. STAT. § 2A:14-32 (1952) (owners who are out of the country are immune); OHIO REV. CODE ANN. § 2305.04 (Page 1981) (includes prisoners among the "disabled"). 
Possession as the basis of property ownership, then, seems to amount to something like yelling loudly enough to all who may be interested. The first to say, "This is mine," in a way that the public understands, gets the prize, and the law will help him keep it against someone else who says, "No, it is mine." But if the original communicator dallies too long and allows the public to believe the interloper, he will find that the interloper has stepped into his shoes and has become the owner.

Similar ideas of the importance of communication, or as it is more commonly called, "notice," are implicit in our recording statutes and in a variety of other devices that force a property claimant to make a public record of her claims on pain of losing them altogether. ${ }^{36}$ Indeed, notice plays a part in the most mundane property-like claims to things that the law does not even recognize as capable of being reduced to ownership. "Would you please save my place?" one says to one's neighbor in the movie line, in order to ensure that others in line know that one is coming back and not relinquishing one's claim. ${ }^{37}$ In my home town of Chicago, one may choose to shovel the snow from a parking place on the street, but in order to establish a claim to it one must put a chair or some other object in the cleared space. ${ }^{38}$ The useful act of shoveling snow does not speak as unambiguously as the presence of an object that blocks entry.

Why, then, is it so important that property owners make and keep their communications clear? Economists have an answer: clear titles facilitate trade and minimize resource-wasting conflict. If I am careless about who comes on to a corner of my property, I invite others to make mistakes and to waste their labor on improvements to what I have allowed them to think is theirs. I thus invite a free-for-all over my ambiguously held claims, and I encourage contention, insecurity, and litigation-all of which waste

${ }^{36}$ For a recording statute that recognizes only those real-property claims that have been recorded, see N.C. GEN. STAT. $\$ 47-18(a)$ (1976). For the United States' efforts to require that holders of inchoate claims on public mineral lands record their claims, on pain of losing them, see Federal Land Policy and Management Act of 1976, § 314, 43 U.S.C. $\S 1744$ (c) (1982). For a discussion of marketable-title statutes, which extinguish stale land claims except insofar as the claimants file notice of the claim, see Barnett, Marketable Title Acts-Panacea or Pandemonium?, 53 CoRnell L. Rev. 45 (1967).

${ }^{37}$ For notice elements in claims to places in line, see On the Pressures and Politics of Waiting in Line, N.Y. Times, Feb. 11, 1982, at C1, C7, col. 1 (claims staked by "saving places" and leaving objects; one entrepreneur distributes numbered tickets for places in the standing-room line at the opera).

ss See Chicago Tribune, Jan. 27, 1985, $\S 2$, at 1 , col. 1 (picture of chairs placed in shoveled parking spaces). 
everyone's time and energy and may result in overuse or underuse of resources. But if I keep my property claims clear, others will know that they should deal with me directly if they want to use my property. We can bargain rather than fight; through trade, all items will come to rest in the hands of those who value them most. If property lines are clear, then, anyone who can make better use of my property than I can will buy or rent it from me and turn the property to his better use. In short, we will all be richer when property claims are unequivocal, because that unequivocal status enables property to be traded and used at its highest value..$^{39}$

Thus, it turns out that the common law of first possession, in rewarding the one who communicates a claim, does reward useful labor; the useful labor is the very act of speaking clearly and distinctly about one's claims to property. Naturally, this must be in a language that is understood, and the acts of "possession" that communicate a claim will vary according to the audience. Thus, returning to Pierson $v$. Post, the dissenting judge may well have thought that fox hunters were the only relevant audience for a claim to the fox; they are the only ones who have regular contact with the subject matter. By the same token, the mid-nineteenthcentury California courts gave much deference to the mining-camp customs in adjudicating various Gold Rush claims; the FortyNiners themselves, as those most closely involved with the subject, could best communicate and interpret the signs of property claims and would be particularly well served by a stable system of symbols that would enable them to avoid disputes. ${ }^{40}$

The point, then, is that "acts of possession" are, in the now fashionable term, a "text," and that the common law rewards the author of that text. But, as students of hermeneutics know, the

39 See Richard Posner, Economic Analysis of Law 27-31 (2d ed. 1977). For critiques of this analysis, see Kennedy \& Michelman, Are Property and Contract Efficient?, 8 HoFSTRA L. Rev. 711, 717-20 (1980); Michelman, Ethics, Economics and the Law of Property, 24 Nomos 3 (1982); for critiques of these two articles, respectively, see Baker, Starting Points in Economic Analysis of Law, 8 Hofstra L. Rev. 939, 957-65 (1980); Demsetz, Professor Michelman's Unnecessary and Futile Search for the Philosopher's Touchstone, 24 Nomos 41 (1982).

10 See McCurdy, Stephen J. Field and Public Land Law Development in California, 1850-1866: A Case Study of Judicial Resource Allocation in Nineteenth-Century America, 10 LAw \& Soc'y Rev. 235, 239-41 (1976). McCurdy also notes, however, that there were implicit conflicts between first arrivals and latecomers to the mining areas and that the courts had to devise rules for deciding cases where one or the other group attempted to change mining-district rules to its own advantage. Id. at 242-46; cf. Umbeck, $A$ Theory of Contract Choice and the California Gold Rush, 20 J.L. \& Econ. 421, 422-28 (1977) (economic analysis of the types of claim agreements made by miners). 
clearest text may have ambiguous subtexts. ${ }^{41}$ In connection with the text of first possession, there are several subtexts that are especially worthy of note. One is the implication that the text will be "read" by the relevant audience at the appropriate time. It is not always easy to establish a symbolic structure in which the text of first possession can be "published" at such a time as to be useful to anyone. Once again, Pierson v. Post illustrates the problem that occurs when a clear sign (killing the fox) comes only relatively late in the game, after the relevant parties may have already expended overlapping efforts and embroiled themselves in a dispute. Very similar problems occurred in the whaling industry in the nineteenth century: the courts expended a considerable amount of mental energy in finding signs of "possession" that were comprehensible to whalers from their own customs and that at the same time came early enough in the chase to allow the parties to avoid wasted efforts and the ensuing mutual recriminations. ${ }^{42}$

Some objects of property claims do seem inherently incapable of clear demarcation-ideas, for example. ${ }^{43}$ In order to establish ownership of such disembodied items we find it necessary to translate the property claims into sets of secondary symbols that our culture understands. In patent and copyright law, for example, one establishes an entitlement to the expression of an idea by translating it into a written document and going through a registration process-though the unending litigation over ownership of these expressions, and over which expressions can even be subject to patent or copyright, might lead us to conclude that these particular secondary symbolic systems do not always yield widely understood "markings." 44 We also make up secondary symbols for physical ob-

4 See, e.g., Stanley Fish, Is There a Text in This Class? 29 (1980).

42 See, e.g., Swift v. Gifford, 23 F. Cas. 558 (D. Mass. 1872) (No. 13,696); Aberdeen Arctic Co. v. Sutter, 149 Rev. Rep. 358 (H.L. 1862) (Scot.); Hogarth v. Jackson, 2 Car. \& P. 595, 172 Eng. Rep. 271 (K.B. 1827); Fennings v. Grenville, 1 Taunt. 241, 127 Eng. Rep. 825 (C.P. 1808).

is See, e.g., Millar v. Taylor, 4 Burr. 2303, 2356-58, 98 Eng. Rep. 201, 230-31 (K.B. 1769) (Yates, J., dissenting) (mere ideas, being incorporeal, cannot be subject to possession or ownership); Wheaton v. Peters, 33 U.S. (8 Pet.) 591, 672-73 (1834) (Thompson, J., dissenting) (same).

"For an extreme example of the failure of the copyright system to give clear notice of ownership of songs, see Arnstein v. Porter, 154 F.2d 464 (2d Cir. 1946), in which the court, in an opinion by Judge Frank, held that the author of "The Lord Is My Shepherd" was entitled to a trial on the merits of whether Cole Porter's "Begin the Beguine" infringed his copyright! Cf. Apple Computer, Inc. v. Franklin Computer Corp., 714 F.2d 1240 (3d Cir. 1983), cert. dismissed, 104 S. Ct. 690 (1984) (computer operating system software may be copyrighted). In the case of computer software, it has been suggested that the invention might better have been handled as a patent, except that the lead time for patents is so long 
jects that would seem to be much easier to mark out than ideas; even property claims in land, that most tangible of things, are now at their most authoritative in the form of written records. ${ }^{45}$

It is expensive to establish and maintain these elaborate structures of secondary symbols, as indeed it may be expensive to establish a structure of primary symbols of possession. The economists have once again performed a useful service in pointing out that there are costs entailed in establishing any property system. ${ }^{46}$ These costs might prevent the development of any system at all for some objects, where our need for secure investment and trade is not as great as the cost of creating the necessary symbols of possession.

There is a second and perhaps even more important subtext to the "text" of first possession: the tacit supposition that there is such a thing as a "clear act," unequivocally proclaiming to the universe one's appropriation-that there are in fact unequivocal acts of possession, which any relevant audience will naturally and easily interpret as property claims. Literary theorists have recently written a great deal about the relativity of texts. They have written too much for us to accept uncritically the idea that a "text" about property has a natural meaning independent of some audience constituting an "interpretive community"47 or independent of a range of other "texts" and cultural artifacts that together form a symbolic system in which a given text must be read. ${ }^{48}$ It is not

that it would make the "property" right useless in such a rapidly changing field-hence the choice of the more rapid copyright system. See Sanger, The Gavel Comes Down on Computer Copycats, N.Y. Times, Oct. 23, 1983, § 3, at 8, col. 1. The Apple Computer analysis further suggests that secondary systems for establishing rights in "uncatchable" property may not be immune from the disputes and overlapping use that often accompany unclear property claims. See supra note 39 and accompanying text.

${ }^{45}$ See supra note 36 and accompanying text.

18 See, e.g., Anderson \& Hill, The Evolution of Property Rights: A Study of the American West, 18 J.L. \& EcoN. 163, 168-78 (1975) (property-rights systems for Western land, livestock, and water were developed only when the benefits of such systems overcame the administrative costs of establishing them); Umbeck, supra note 40, at 421-28 (choice of property system subject to constraint of transaction costs); see also Michelman, supra note 39, at 30-31 (private property is a type of regulatory system).

47 See Terry Eagleton, Literary Theory 74-88 (1983) (meaning of a text is indeterminable unless readers share common understanding of its elements); S. Fish, supra note 41, at 239-44 (communication requires agreed-upon language conventions).

${ }^{4}$ See, e.g., T. EAGLETON, supra note 47, ch. 4 (all literary texts are "woven out of" prior and contemporaneous elements). Some of these authors regard the meaning of any text as radically unstable, since all texts may be said to depend on all others for proper understanding: no one writes upon a slate that is even remotely clean. See, e.g. ChrIstopher NorRIS, Deconstruction: Theory and Practice 24-32 (1982) (elements of language and texts take their meanings by reference to, and in differentiation from, other elements of language and 
enough, then, for the property claimant to say simply, "It's mine" through some act or gesture; in order for the "statement" to have any force, some relevant world must understand the claim it makes and take that claim seriously.

Thus, in defining the acts of possession that make up a claim to property, the law not only rewards the author of the "text"; it also puts an imprimatur on a particular symbolic system and on the audience that uses this system. Audiences that do not understand or accept the symbols are out of luck. For Pierson's dissenting judge, who would have made the definition of first possession depend on a decision of hunters, the rule of first possession would have put the force of law behind the mores of a particular subgroup. The majority's "clear act" rule undoubtedly referred to a wider audience and a more widely shared set of symbols. But even under the majority's rule, the definition of first possession depended on a particular audience and its chosen symbolic context; some audiences win, others lose.

In the history of American territorial expansion, a pointed example of the choice among audiences made by the common law occurred when one group did not play the approved language game and refused to get into the business of publishing or reading the accepted texts about property. The result was one of the most arresting decisions of the early American republic: Johnson v. McIntosh, ${ }^{48}$ a John Marshall opinion concerning the validity of opposing claims to land in what is now a large part of Illinois and Indiana. The plaintiffs in this case claimed through Indian tribes, on the basis of deeds made out in the 1770's; the defendants claimed under titles that came from the United States. ${ }^{50}$ The Court found for the defendants, holding that the claims through the Indians were invalid, for reasons derived largely from international law rather than from the law of first possession. But tucked away in the case was a first-possession argument that Marshall passed over. The Indians, according to an argument of the claimants from the United States, could not have passed title to the opposing side's predecessors because, "[b]y the law of nature," the Indians themselves had never done acts on the land sufficient to establish property in it. That is to say, the Indians had never really undertaken

texts).

1321 U.S. (8 Wheat.) 543 (1823).

so The United States' claims came through Virginia, which had ceded its western lands to the United States after the Revolutionary War. Id. at 559. 
those acts of possession that give rise to a property right..1

Although Marshall based his decision on other grounds, ${ }^{52}$ there was indeed something to the argument from the point of view of the common law of first possession. Insofar as the Indian tribes moved from place to place, they left few traces to indicate that they claimed the land (if indeed they did make such claims). ${ }^{53}$ From an eighteenth-century political economist's point of view, the results were horrifying. What seemed to be the absence of distinct claims to land among the Indians merely invited disputes, which in turn meant constant disruption of productive activity and dissipation of energy in warfare. Uncertainty as to claims also meant that no one would make any productive use of the land because there is little incentive to plant when there is no reasonable assurance that one will be in possession of the land at harvest time. ${ }^{54}$ From this classical economic perspective, the Indians' alleged indifference to well-defined property lines in land was part and parcel of what seemed to be their relatively unproductive use of the earth. ${ }^{\text {ss }}$

${ }^{31}$ Id. at $569-70$.

52 Id. at 588 ("We will not enter into the controversy, whether agriculturists, merchants, and manufacturers, have a right, on abstract principles, to expel hunters from the territory they possess . . . . Conquest gives a title which the courts of the conqueror cannot deny ....").

${ }^{83}$ See infra note 55 and accompanying text. It should be noted that even at the time of English settlement, a number of eastern tribes did farm and live in villages, some with substantial structures. See R.C. Simmons, The American Colonies from Setrlement to IndePENDENCE 156 (1976) (Iroquois villages were protected by log palisades, with crops outside; southeastern tribes generally lived in farming and hunting villages); WrLIAM CronoN, Changes in the Land: Indians, Colonists, and the Ecology of New England 56 (1983) (New England Indians grew crops; their crop areas were the only lands recognized as Indian property by English settlers).

s4 See Jeremy Bentham, Theory of Legislation pt. 1, ch. 10, at 118 (R. Hildreth trans. 1864) (1st ed. Paris 1802) (lack of security of property in the North American interior results in warring tribes and lack of civil improvements; security of property in European settlements results in growing cities, cultivation, roads, wealthier and much more numerous populace); see also J. Locke, supra note $2, \S 37$, at 335-36 (comparing the unproductive character of "the wild woods and uncultivated wast [sic] of America left to Nature" with the enclosed and improved lands of Devonshire); 2 W. BLAckstone, supra note 6, at *7:

[W] ho would be at the pains of tilling [the soil], if another might watch an opportunity to seise upon and enjoy the product of his industry, art, and labour? Had not therefore a separate property in lands, as well as moveables, been vested in some individuals, the world must have continued a forest, and men have been mere animals of prey; which, according to some philosophers, is the genuine state of nature.

William Cronon, supra note 53, at 53,56-57, argues that the lack of fixed improvements on Indian land gave European settlers an excuse for dispossessing them, though some settlers argued that Indian practices of burning the forests prior to hunting sufficed to establish a property claim.

ss See supra note 54. From the perspective of a hunting people, however, definite property in land may seem undesirable and indeed may cause insecurity. A recent example is the 
Now it may well be that North American Indian tribes were not so indifferent to marking out landed property as eighteenthcentury European commentators supposed. Or it may be that at least some tribes found landed property less important to their security than other forms of property and thus felt no need to assert claims to property in land..$^{56}$ But however anachronistic the Johnson parties' (ultimately mooted) argument may now seem, it is a particularly striking example of the relativity of the "text" of possession to the interpretative community for that text. It is doubtful whether the claims of any nomadic population could ever meet the common law requirements for establishing property in land. ${ }^{57}$ Thus, the audience presupposed by the common law of first possession is an agrarian or a commercial people-a people whose activities with respect to the objects around them require an unequivocal delineation of lasting control so that those objects can be managed and traded..$^{58}$

But perhaps the deepest aspect of the common law text of possession lies in the attitude that this text strikes with respect to the relationship between human beings and nature. At least some Indians professed bewilderment at the concept of owning the land. Indeed they prided themselves on not marking the land but rather on moving lightly through it, living with the land and with its creatures as members of the same family rather than as strangers who visited only to conquer the objects of nature..$^{59}$ The doctrine of first

series of complicated land settlements that have arisen under the Alaska Native Claims Settlement Act of 1971, 43 U.S.C. $\S \S 1601-1624$ (1982). Some Native American corporations have objected to selection of specific lands as tribal property because they think this may prevent them from following the migratory herds that supply their livelihood. See Parfit, Alaska's Natives Are Bringing Off the Biggest Corporate Takeover, Smithsonian MaG., Aug. 1981, at 30; cf. Demsetz, Toward a Theory of Property Rights, 57 AM. Econ. REv. Proc. 347, 351-53 (1967) (scarcity of animals may lead to establishment of property rights among hunting populations, so that individual hunters husband animals in alloted areas; this thesis is applicable, however, only to the hunting of animals that do not roam widely).

${ }_{36}$ But see R.C. Simmons, supra note 53, at 156 (some eastern tribes settled in villages).

37 This argument was made by the Johnson defendants, 21 U.S. ( 8 Wheat.) at 569-70.

ss Marxists would doubtless see in these common law property doctrines still further proof of the relationship of ideas to economic substructure. The law of first possession-the rule that a clear and visible demarcation of a claim should confer some right-would be seen as just another item in the intellectual baggage of capitalist production.

30 This attitude is reflected in a letter from an elderly Indian chief to President Franklin Pierce in 1855, described in C. HaAr \& L. Liebman, Property and Law 15 (1977). After stating that the Indians did not see the land as something to be owned, the letter went on: "We know that white man does not understand our ways[, . . . for he is a stranger who comes in the night and takes from the land whatever he needs. The earth is not his brother but his enemy, and when he has conquered it he moves on." See also Silko, They Were the Land's, N.Y. Times, May 25, 1980, § 7 (Book Review), at 10, col. 1 (describing sense of 
possession, quite to the contrary, reflects the attitude that human beings are outsiders to nature. It gives the earth and its creatures over to those who mark them so clearly as to transform them, so that no one else will mistake them for unsubdued nature. ${ }^{60}$

We may admire nature and enjoy wildness, but those sentiments find little resonance in the doctrine of first possession. Its texts are those of cultivation, manufacture, and development. We cannot have our fish both loose and fast, as Melville might have said, ${ }^{61}$ and the common law of first possession makes a choice. The common law gives preference to those who convince the world that they have caught the fish and hold it fast. This may be a reward to useful labor, but it is more precisely the articulation of a specific vocabulary within a structure of symbols approved and understood by a commercial people. It is this commonly understood and shared set of symbols that gives significance and form to what might seem the quintessentially individualistic act: the claim that one has, by "possession," separated for oneself property from the great commons of unowned things.

kinship between Indian tribes and the land).

${ }^{60}$ For the longstanding European history of aversion to unsubdued nature, see Roderick Nash, Wilderness and the American Mind ch. 1 (rev. ed. 1973).

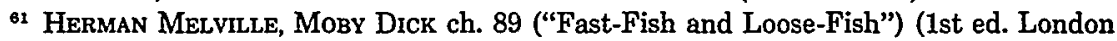
1851). This chapter describes some litigation over ownership of a whale that had been harpooned but got away, harpoon and all, only to be harpooned and taken by a second crew. The legal question involved the point at which the whale stopped being a "loose-fish" and became a "fast-fish"-that is, the point at which the whale became someone's property. Melville goes on to describe a number of items (including serfs and mortgages) as "fast-fish" and a number of other items (America at Columbus' arrival, ideas, the rights of man) as "loose-fish." 